\title{
Tax Incentives for Affordable Housing: The Low Income Housing Tax Credit
}

\section{Citation}

Desai, Mihir, Dhammika Dharmapala, and Monica Singhal. "Tax Incentives for Affordable Housing: The Low Income Housing Tax Credit." Tax Policy and the Economy 24.1 (2010): 181-205.

\section{Published Version}

http://dx.doi.org/10.3386/w14149

\section{Permanent link}

http://nrs.harvard.edu/urn-3:HUL.InstRepos:10611680

\section{Terms of Use}

This article was downloaded from Harvard University's DASH repository, and is made available under the terms and conditions applicable to Other Posted Material, as set forth at http:// nrs.harvard.edu/urn-3:HUL.InstRepos:dash.current.terms-of-use\#LAA

\section{Share Your Story}

The Harvard community has made this article openly available.

Please share how this access benefits you. Submit a story.

Accessibility 


\title{
Tax Incentives for Affordable Housing: The Low Income Housing Tax Credit
}

\author{
Mihir Desai, Harvard University and NBER \\ Dhammika Dharmapala, University of Illinois at Urbana-Champaign \\ Monica Singhal, Harvard University and NBER
}

\section{Executive Summary}

The Low Income Housing Tax Credit (LIHTC) represents a novel tax expenditure program that employs "investable" tax credits to spur production of low-income rental housing. While it has grown into the largest source of new affordable housing in the United States and its structure is now being replicated in other programs, the LIHTC has also drawn skepticism and calls for its repeal. We provide estimates of tax expenditures under this program and discuss pricing, efficiency, and distributional effects of the program. We also consider the impacts of the recent financial crisis on the LIHTC program and explore implications of resulting policy changes and proposals.

\section{Introduction}

The Low Income Housing Tax Credit (LIHTC) program provides for the majority of new affordable housing units built in the United States and has resulted in the production of 1.5 million low-income housing units since its inception in 1986. The LIHTC represents a radical departure from the structure of previous supply-side housing programs, which have generally relied on direct provision or subsidization of low-income housing. In addition to being a critical federal housing program, the LIHTC is of interest as an example of a novel type of tax expenditure program that is spreading to other policy domains. Under the LIHTC program, the government allocates tax credits to developers of low-income housing, who then sell the credits, often via intermediaries, to investors in exchange for equity financing. Credits are subsequently claimed by investors on their tax returns. As a consequence, the tax beneficiary is an investor rather than the provider or the targeted beneficiary of the subsidized service. We refer to this class of credits as "investable tax credits." 
Figure 1 illustrates the rapid growth in tax expenditures for this program. Annual tax expenditures on the LIHTC program were estimated at $\$ 4.3$ billion in 2004 and are projected to increase by almost $20 \%$ in real terms by 2011 (JCT, various years). ${ }^{1}$ Expenditures on the LIHTC program relative to other federal housing programs are shown in figure 2 . While tax expenditures on the LIHTC are only about a third of outlays on Section 8 vouchers, the program is large relative to other federal supply-side programs. In addition, several of these other programs (such as the Section 8 Project-Based Program) are no longer active (Rice and Sard 2007). The LIHTC is currently the largest and fastest-growing federal program for the production of affordable rental housing.

Although the LIHTC has generally been regarded with skepticism in the academic literature (e.g., Weisbach 2006), the program has remained politically popular. Reforms to the program since its inception have all been in the direction of program expansion and have generally passed with overwhelming bipartisan support. In addition, other programs with a similar structure have been introduced by the federal government. Under the New Market Tax Credits program, for example, the federal government allocates tax credits to designated Community Development Entities (CDEs). The CDE then sells these credits to investors in exchange for equity finance, which is used by the CDE to provide investments in

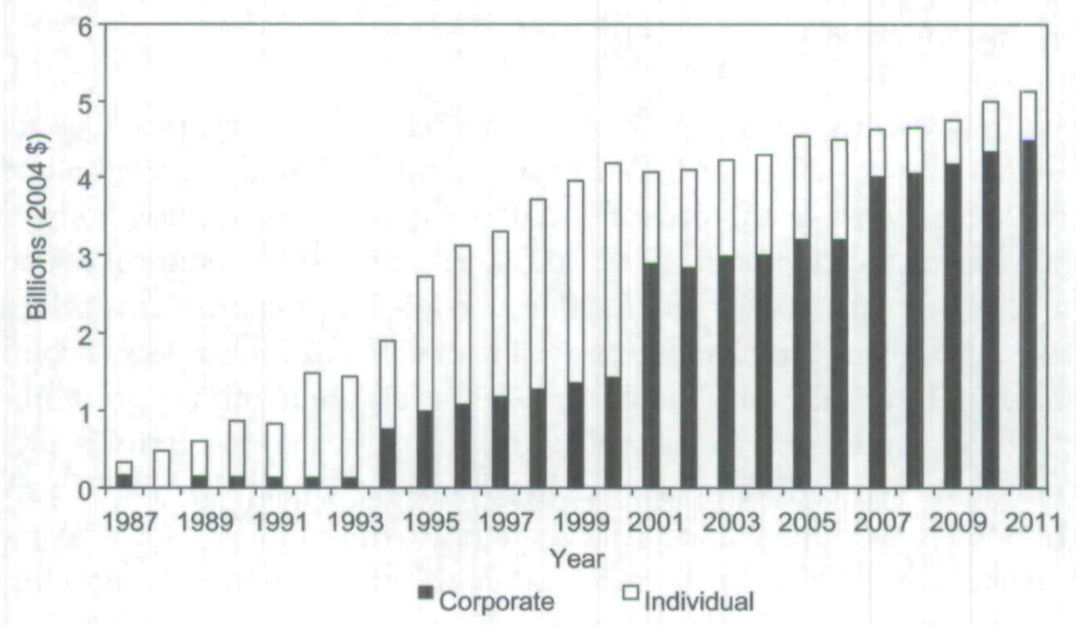

Fig. 1. JCT estimates of LIHTC tax expenditure. Source: JCT (various years). Figures for a given year are taken from the report immediately preceding that year. All figures are in 2004 dollars. Starting from 2008, estimates are based on a -0.3 annual change in the consumer price index, which reflects the average for 2005-7. The apparent 1-year shift from individual to corporate claimants from 2000 to 2001 reflects a change in the method of estimation rather than a true change in the distribution of claimants. 


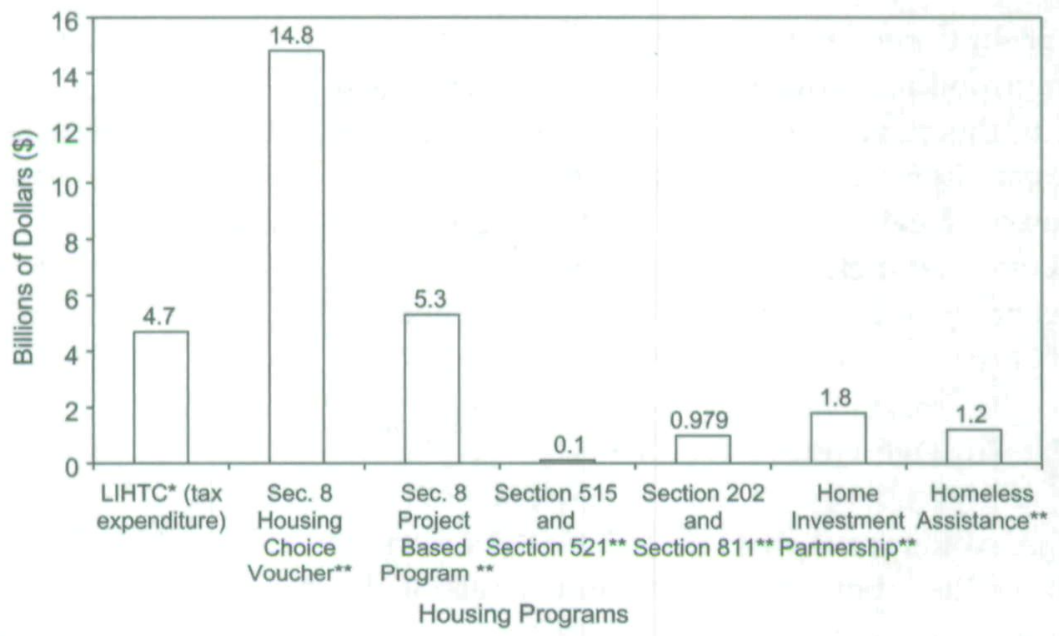

Fig. 2. Comparison of housing programs (2005). Sources: *Data for LIHTC tax expenditure are from JCT (various years). ${ }^{* *}$ Data on remaining programs come from Rice and Sard (2007). Funding estimates for these programs are based on budget authority rather than expenditure. The Section 8 Housing Choice Voucher program provides vouchers to low-income tenants. The Section 8 Project-Based Program subsidizes affordable rental housing. Section 515 and Section 521 provide low-interest loans to encourage the production of affordable rental housing in rural areas. Section 202 and Section 811 provide subsidies to developers of affordable rental housing for the elderly and those with disabilities; Section 811 also includes tenant-based rental assistance for the disabled. The Home Investment Partnership provides a variety of subsidies (both project and tenant based) for rental and nonrental affordable housing. Homeless assistance refers to a number of programs that provide housing assistance to the homeless. See Rice and Sard (2007) for further details.

low-income communities. The program was initiated in 2000 and has allocated \$12.1 billion in tax credits as of 2007 (GAO 2007). Recent legislation has also proposed the creation of a Homeowner's Tax Credit, modeled after the LIHTC, for the construction or rehabilitation of nonrental affordable housing. ${ }^{2}$

The LIHTC program has also received a great deal of recent attention, as the market for credits has been severely affected by the financial crisis that began in 2007. Prices for LIH credits have fallen dramatically through 2008 and 2009. This strain in the credit market has come precisely at a time when the need for affordable housing has arguably increased greatly. These recent events have prompted the passage of new legislative initiatives and proposals for further policy reform. In particular, both the Housing and Recovery Act of 2008 (HERA) and the American Recovery and Reinvestment Act of 2009 (ARRA) resulted in important changes to the LIHTC program. Many of these changes are temporary, 
but some permanently affect the structure of the program. We discuss these policies in detail below.

In this paper, we provide estimates of the magnitude of LIHTC tax expenditures and discuss efficiency costs of the program. We also present empirical evidence on the characteristics of program participants: developers, credit claimants, and beneficiaries. Finally, we discuss recent events in the LIHTC market as well as the potential implications of recent tax legislation and reform proposals.

\section{An Overview of the LIHTC}

The Tax Reform Act of 1986 (TRA86) included several provisions that reduced the profitability of investment in rental housing. The LIHTC program was devised as part of TRA86 to preserve incentives for the provision of affordable rental housing. Under this program, the Internal Revenue Service (IRS) allocates nonrefundable tax credits to housing agencies run by the state governments, which then award the credits to selected housing projects proposed by developers. Federal law sets basic requirements for projects applying for LIHTC funds to ensure that they make a strong commitment to provide low-income housing. However, state housing agencies hold most of the power in selecting program recipients, both through their individual plans for ranking programs and through a significant amount of additional discretion. Developers, in turn, sell the credits to investors in exchange for equity financing used to support the housing project. Investors may be individuals, corporations, or financial institutions, and their return is limited to their tax benefits. Intermediaries, also known as syndicators, create the market in these tax credits. The flow of credits is depicted in simplified form in figure 3, based on GAO (1997). ${ }^{3}$

There are two types of credits allocated under the program. The first type of credit ("9\% credit") is allocated to projects that are newly constructed and receive no other federal subsidies. The federal government allocates these credits to states in proportion to population. Initial allocations were $\$ 1.25$ per capita. This amount was increased (in nominal terms) to $\$ 1.50$ in 2002 and to $\$ 1.75$ in 2003 and was indexed for inflation thereafter. These allocations are subject to a small state minimum, which was $\$ 2$ million in 2003 and was also indexed for inflation. If a project is financed with private-activity tax-exempt bonds, it is eligible for the second type of credit (" $4 \%$ credit"); these credits are capped only indirectly through state private activity bond caps. 

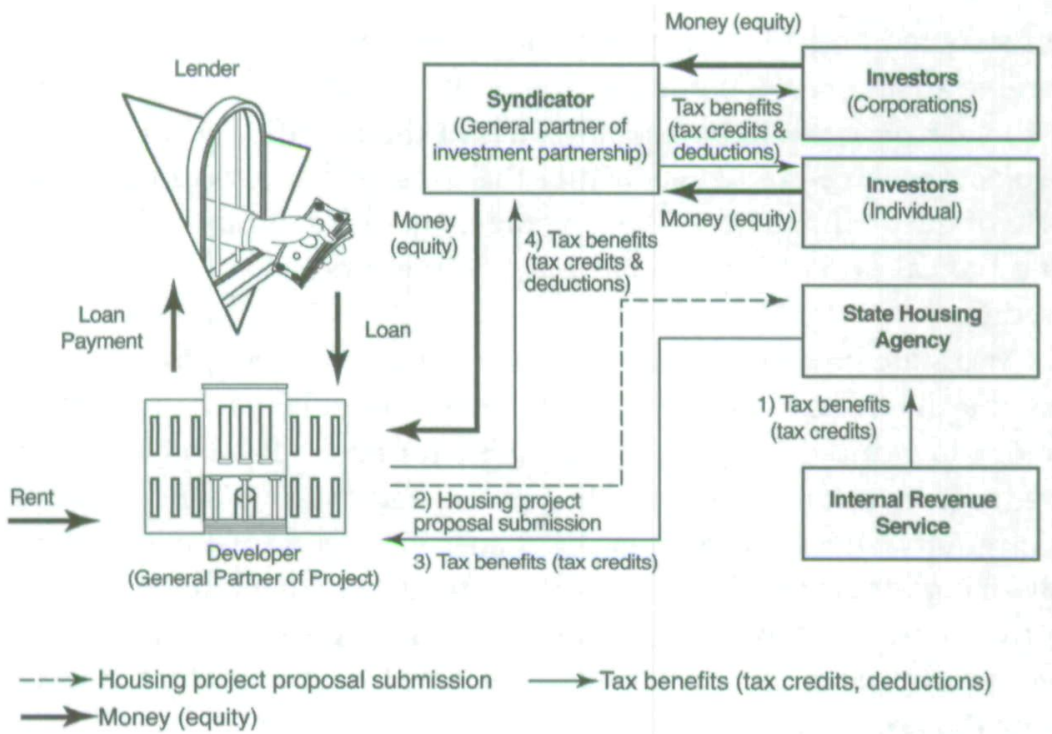

Fig. 3. Mechanics of LIHTC allocation. Source: Adapted from GAO (1997)

One dollar of allocated credit entitles the claimant to a dollar tax credit each year for a 10 -year period. The federal government also sets several guidelines with which projects must comply in order to be eligible for LIHTC funding. Most important, a certain share of units must be rent restricted and be occupied by low-income households. These conditions must, in most cases, be met for a minimum of 30 years. ${ }^{4}$ Conditional on meeting these guidelines, state housing agencies have broad discretionary powers in setting criteria for the credit allocation process. These criteria are generally set out in state Qualified Action Plans (QAPs). The normal allocation process can be overridden or bypassed; indeed, a General Accounting Office study found that 17 out of 20 studied QAPs contained such override provisions (GAO 1997). Olsen (2003) estimates that, on average, $\$ 3$ is requested for every available $\$ 1$, indicating periods of substantial excess demand for LIH credits. As a result, many states have forced developers to meet requirements that are stricter than the federal guidelines in order to be eligible for these credits. ${ }^{5}$

Tax credits are then awarded to chosen projects. The amount of tax credits a given project receives is determined by the qualified basis of the project. This is the product of two factors: the first reflects the development costs of the project, and the second reflects the share of the project that is reserved as low-income. ${ }^{6}$ This method approximates a subsidy per low-income unit, adjusted for development costs. Projects that are newly 
constructed and receive no federal subsidies other than the LIHTC receive an amount of credits such that the present value of credits over a 10 -year period will be equal to $70 \%$ of the qualified basis. All other projects receive credits such that the present value will be equal to $30 \%$ of the qualified basis. ${ }^{7}$ On average, one-third of the total financing of a typical project is provided through the proceeds of the sale of tax credits.

Once state housing agencies award credits to projects, the tax credits become available to the developer. The developer may either use the tax credits to reduce its own tax bills, if it is a for-profit developer, or sell the credits to investors. Investors who buy the credits provide the developers with equity, which is used to support the construction and creation of the low-income housing. The deal is often structured as a limited partnership between investors and developers. Investors, the limited partners in the partnership, generally do not expect income from the equity but instead view the tax credits as their return.

Note that the structure of the program creates tax benefits for investors and intermediaries in the syndication process who have no intrinsic interest in low-income housing or related issues. This creates a much wider constituency for the program than would be the case for an economically equivalent program of direct subsidies for low-income housing. ${ }^{8}$ This may explain why developers, intermediaries, and housing advocatesnot by any means a natural political coalition-are fans of the program. ${ }^{9}$

\section{LIHTC Tax Expenditure Estimates}

In this section, we consider two methods to calculate tax expenditures under the LIHTC program and compare the resulting estimates to the Joint Committee on Taxation (JCT) estimates. First, we calculate implied tax expenditures from credits allocated. As discussed above, the LIHTC differs from most other tax expenditures in that a large share of total expenditure is capped and determined by annual per capita credit allocations. If the majority of credits are claimed, it should be possible to estimate and project tax expenditures under this program with a reasonably high degree of accuracy using only information on credits allocated. Second, we calculate tax expenditures using data from individual and corporate tax returns. As we discuss below, the information on the public-use files is not always sufficient to calculate actual credits claimed. We therefore compare the resulting tax expenditure estimates to the estimates from JCT and credits allocated to assess the validity of using these data to examine the characteristics of credit claimants. 


\section{A. Estimates from Credits Allocated}

Figure 4 provides expenditure estimates based on credits allocated. All credits allocated by the federal government are assumed to be claimed by investors over the 10-year period immediately following project completion, with a 2-year lag between credit allocation and project completion. Annual credits claimed are then adjusted to 2004 dollars. This method will result in underestimates of total tax expenditures since it accounts only for credits subject to the per capita cap.

Implied expenditures increase rapidly over the first decade as the program reaches steady state. Expenditures then decline slightly as the real value of credits allocated falls over time and increase as annual per capita allocations are increased. Expenditure estimates are substantially higher than JCT estimates in the early years of the program but conform closely to JCT estimates over the recent period. This likely reflects the fact that many of the initially allocated tax credits were left unused (GAO 1997). Lags between federal allocation and credit claiming may also have been longer than average in the early years of the program.

\section{B. Estimates from Tax Return Data}

A second measure of LIHTC tax expenditure comes from credits claimed by individuals and corporations on their tax returns. There

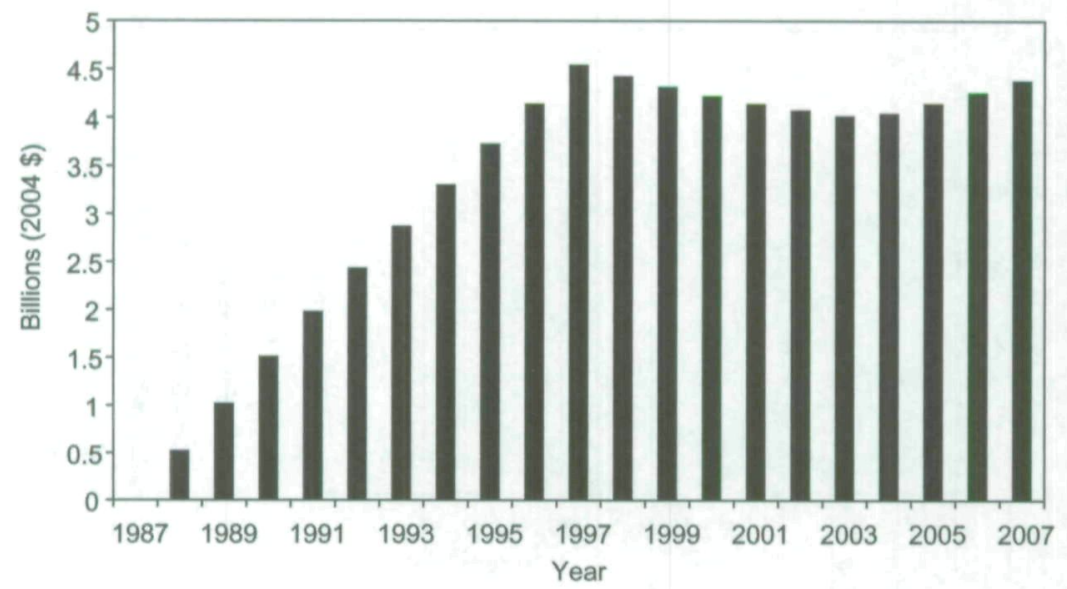

Fig. 4. Tax expenditure estimates from credits allocated. Figures are calculated from annual per capita credits allocated and population figures and assume that all credits are claimed over the 10-year period following project completion. The figures are based on federal allocation guidelines and do not incorporate state-specific minimum allocations or changes arising from 2008 and 2009 legislation. We allow a 2-year lag between allocation and project completion. 
are at least three reasons why information on credits claimed from tax return data may not accurately reflect actual annual tax expenditure on the LIH program. ${ }^{10}$ First, the line item for the current-year LIHTC is included as part of the tentative credit calculation form for the general business tax credit (Form 3800). Taxpayers may not be eligible to claim the full amount of the tentative credit; for example, credits are nonrefundable and cannot be used to offset alternative minimum tax (AMT) liability. ${ }^{11}$ Although the total amount of general business tax credit claimed is available on the tax return, it is difficult to determine the exact amount of credit claimed for these taxpayers. Second, LIH credits can in some cases be carried forward or carried back. In these cases, they are included as single line items that include the sum of all general business credit carryforwards or carrybacks. Finally, an individual does not need to file Form 3800 if she is not claiming any other general business credits and has no carryforwards or carrybacks. The allowable LIH credits are then entered in the "other credits" line item on Form 1040. While the first factor may cause these estimates to represent an overestimate, the second two factors may result in underestimates of total LIH credits claimed from the Form 3800 line item.

Given these caveats, estimates of LIHTC tax expenditure based on publicly available individual and corporate tax return data are presented in figure 5. The individual data come from public-use samples of individual federal tax returns. ${ }^{12}$ Information on LIH credit claiming is available from 1987-2002. The corporate data come from table 21 of the Statistics of Income

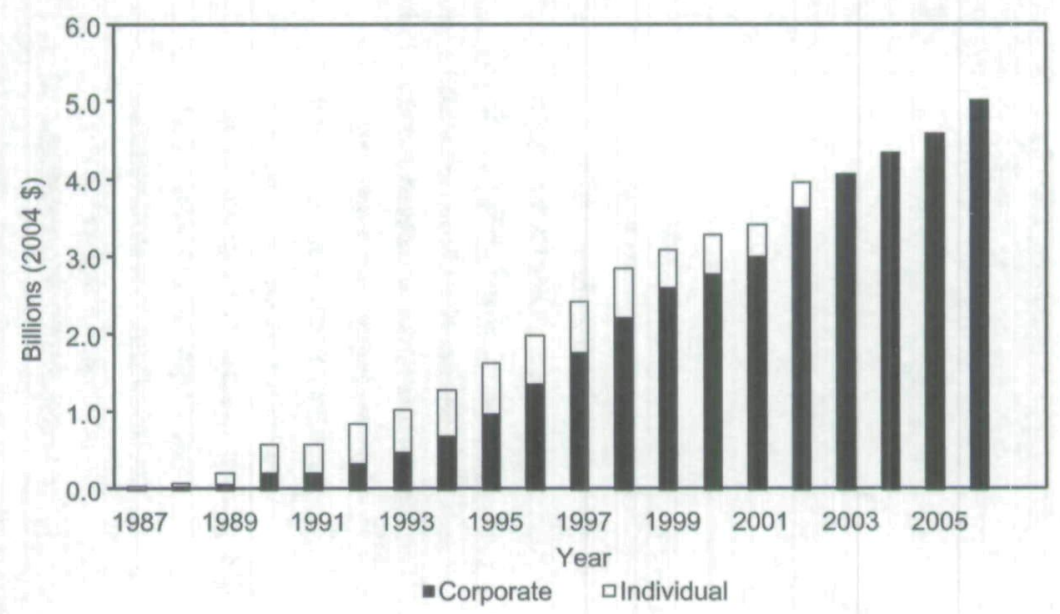

Fig. 5. Tax expenditure estimates from tax return data. Source: Individual data are from 1987-2002. Figures are taken from the tentative credit calculation of the general business tax credit (Form 3800). Individual data are taken from the public-use individual federal tax return sample and corporate data are from the Statistics of Income Corporation Complete Report. 
Corporation Complete Report (http://www.irs.gov/taxstats/article/ 0 ,id $=170734,00 . \mathrm{html})$, which itemizes components of the general business tax credit.

The estimates in figure 5 are lower than estimates from credits allocated in the early years of the program. Again, this is likely a result of initial credits remaining either unused or claimed with a substantial lag. In 2002, the last year for which we have individual data, implied tax expenditure on the program was almost $\$ 4$ billion. Less than $10 \%$ of this expenditure was from claims by individual investors.

The gap between tentative and allowable LIH credits seems likely to be small for two reasons. First, investors must actively purchase credits and would not do so unless they expected to claim the full value. Second, while it is possible that investors could unexpectedly become ineligible to claim the full value, there is a secondary market for credits that allows investors to sell credits they cannot claim. ${ }^{13} \mathrm{~A}$ similar argument applies to carryforwards and carrybacks: such claims would arise if investors are not able to claim the full annual allocation in a given year. One imperfect estimate of the magnitude of these biases is to examine what share of tentative credit dollars is "claimed" by investors with AMT liability. ${ }^{14}$ Using the individual public-use files for 1987-2002, we find that less than $10 \%$ of all individual credit dollars are from AMT payers. The possibility remains that individuals are ineligible to claim the full value of credits for other reasons, and the corporate AMT "claim" share may be quite different from the share for individuals. In addition, some credits claimed by individual investors may not appear on Form 3800 . We unfortunately do not have the necessary data to quantify the magnitude of these biases.

Overall, the estimates from these tax data imply slightly higher tax expenditures than the JCT estimates and estimates from credits allocated, consistent with tentative credits being an overestimate of final credits claimed. However, the aggregate trends over time as well as the shift from individual claims to corporate claims do track the estimates from the other data sources fairly well. We are therefore reasonably confident in using these figures as an approximation of credits claimed when we examine the characteristics of credit claimants below.

\section{Credit Pricing and Economic Efficiency}

\section{A. Determinants of Credit Prices and Trends over Time}

An interesting feature of the LIHTC program is that purchasers of credits do not generally receive income from the property; the difference 
between the purchase price and the value of the credit represents the return on the investment. However, credit prices sometimes deviate from the actuarially fair value. In the case of the LIHTC, the price at which credits are sold has increased substantially over the life of the program. Ernst \& Young (2005) calculates the equity price simply as housing credit equity divided by housing credits. By this measure, median credit prices have increased from approximately $\$ 0.45$ in the early years of the program to over $\$ 0.85$ for projects placed into service in $2005 .{ }^{15}$ Anecdotal evidence suggests that the very low initial pricing was primarily the result of uncertainty about the rules of the system and about how long it would last.

Calculating the price in this way implicitly assumes that investors are realizing the full nominal value of credits received. In practice, however, investors realize the credits over a 10 -year period. To obtain a "true" price, which reflects the equity per effective credit dollar, the stream of tax credits should be discounted. Discounting credits appropriately substantially increases the implied equity price: Cummings and DiPasquale (1999) estimate that the average credit price over their sample period (1987-96) increases from $\$ 0.52$ to more than $\$ 0.70$ if the present value of the stream of credits (using a discount rate of $6.7 \%$ ) is used in the price calculations.

Historical prices below actuarially fair values may have reflected additional compensation for the risk of default: projects may fail to remain in compliance over the full lifetime of the credits. If a property is found to be in noncompliance, the investor forfeits future tax credit claims and must repay one-third of previously claimed credits with interest. The monitoring costs associated with ensuring that the developers are in compliance and the discounting of the risk of developer noncompliance could result in a risk premium. Empirically, this risk premium appears negligible: just before the recent financial crisis, credits were trading at or above their actuarially fair value, consistent with evidence indicating that the ex post probability of punishment appears low. Ernst \& Young (2005) finds that only $0.4 \%$ of surveyed properties had been audited and faced a loss of tax benefits in the form of recapture or disallowance of future claims. ${ }^{16}$ While the average risk of noncompliance may be small, risk may help to explain cross-sectional variation in credit prices. Using data from LIHTC transactions in California, Eriksen (2009) finds that projects with characteristics correlated with an increased risk of noncompliance are associated with lower tax credit prices. This suggests that states may be able to use credit prices as an effective ex ante screening device when choosing how to allocate credits across proposed projects. 
In many respects, the puzzling feature of credit prices (until the very recent period) was not why they are too low, but rather why they appear too high. In recent years, credit prices approached or exceeded one when the stream of tax credits is discounted appropriately. ${ }^{17} \mathrm{~A}$ possible explanation for this anomaly is that for certain financial institutions, investment in lowincome housing can serve to satisfy some of their obligations under the Community Reinvestment Act (CRA). The CRA requires banks and other depository institutions to provide credit throughout their local communities, including in low-income areas. CRA evaluations are subjective and are based on a diffuse set of metrics that are deliberately not quantified. The record of the financial institution is reviewed and taken into account when regulators evaluate applications for deposit facilities or during mergers. As such, there are no specific, quantifiable linkages between LIHTC purchases and CRA ratings, though it is widely acknowledged that LIHTC can count toward the hardest standard for banks, the investment of resources into their low-income communities. A 2003 report estimated that $43 \%$ of low-income housing investors were financial institutions subject to CRA requirements (Ernst \& Young 2003). The interaction with the CRA opens up the possibility that entities may be willing to bid the price of tax credits above their actuarially fair value as they can jointly realize tax advantages and fulfill CRA obligations. ${ }^{18}$ Such mechanisms for increasing the funding for the supply of low-income housing should, however, be balanced against possible inefficiencies stemming from any expansion of CRA obligations.

Credit prices may also experience short-term fluctuations as a result of supply and demand shocks. Most notably, the puncturing of the bubble in the U.S. housing market in 2007 and the subsequent financial crisis of 2008 have had profound consequences for the LIHTC program. Prior to the crisis, $\$ 1$ of tax credits traded at an undiscounted price of nearly $\$ 0.90 ;{ }^{19}$ by early 2009 , the corresponding price had fallen below $\$ 0.70$ (see, e.g., Federal Reserve Bank of Dallas 2009). This price decline reflects decreased investor demand for LIH credits, due principally to two factors. First, the large losses incurred by banks and other financial institutions rendered tax credits significantly less valuable. A second major development was the exit from this market of two major buyers of LIH credits, Fannie Mae and Freddie Mac, which entered government conservatorship in September 2008.

\section{B. Efficiency of the Program}

A notable feature of the LIHTC is that a large share of credits (specifically, the $9 \%$ credits) are capped. This means that there is no budgetary 
uncertainty about the amount of resources committed by the government to low-income housing, which may be politically advantageous. However, there is uncertainty over the actual provision of housing; in particular, lower prices of credits may dictate that fewer housing units are constructed. For example, the decreased market value of LIH credits during the recent crisis has had a severe negative impact on the ability of developers to obtain equity financing through the sale of credits. ${ }^{20}$ At the same time, a number of developments have potentially increased the demand for low-income rental housing. For instance, would-be homeowners now face greater difficulty in obtaining credit to purchase houses. There has also been an increase in unemployment associated with the recession. Demand has also increased from former homeowners whose houses have been foreclosed on or who have decided to abandon houses in which they had negative equity. ${ }^{21}$ This extreme case illustrates a more general issue with the structure of the LIHTC program: credit prices and the supply of affordable housing through this program may fluctuate with aggregate economic conditions.

In addition to variability in the prices of credits, it is important to note that not all of the equity finance received through the sale of credits goes into housing projects; there are a number of transactions costs associated with most LIHTC projects. Indeed, the GAO (1997) estimates, for example, that syndication costs may consume $10 \%-27 \%$ of equity invested in $\mathrm{LIH}$ credit projects. Consistent with this finding, Cummings and DiPasquale (1999) find that the average ratio of net equity to gross equity in their data is 0.71 . Syndication costs appear to be declining over time as the market has become more competitive. It is also important to note that many projects constructed with LIH credits also benefit from additional supply-side subsidies, such as tax-exempt bond financing and Section 515 rural housing loans. In addition, a substantial share of residents in these housing projects are recipients of Section 8 vouchers or other forms of rental assistance. ${ }^{22}$ Therefore, while the LIHTC program is credited with great success in the production of affordable housing, it is not clear that the program would be successful in meeting project goals were it to exist in isolation.

This evidence leaves open the question of whether new construction is the most efficient means of getting housing assistance to low-income households or whether subsidies should instead be provided in the form of demand-side programs, such as vouchers. The relative merits of supplyside programs and vouchers are a subject of ongoing debate, and some (e.g., Weisbach 2006) have advocated replacing the LIHTC with a voucher program. A potential disadvantage of vouchers is their effect on market rents: Susin (2002) and Gibbons and Manning (2006), for example, find 
large effects on rent subsidies on rents. Since rent voucher programs cover only a relatively small fraction of people with low incomes, recipients of vouchers may be better off on balance despite the rent increases, but there is a larger population of low-income nonrecipients who face higher rents without receiving any government assistance. In contrast, supply-side housing policies not only benefit those low-income families that obtain the new housing but also may potentially benefit the wider low-income population through lower market rents (Coate, Johnson, and Zeckhauser 1994).

However, these benefits depend on whether housing provided under this program increases the net supply of low-income housing or simply crowds out other low-income housing. Estimates suggest that crowd-out is likely to be substantial: Sinai and Waldfogel (2005) estimate crowdout of up to two-thirds from government-subsidized housing generally, Malpezzi and Vandell (2002) estimate full crowd-out from the LIHTC program, and Eriksen and Rosenthal (2008) estimate crowd-out of between one-half and one. There is, however, some evidence that the LIHTC program increases supply at very local levels. Baum-Snow and Marion (2009) exploit a discontinuity in the LIHTC program. Specifically, a census tract qualifies for discontinuously higher funding (a $30 \%$ increase in the tax credit) if more than $50 \%$ of its households have incomes below a certain threshold ( $60 \%$ of area median gross income). They find a large impact of this discontinuity on the supply of LIHTC housing. They also find that LIHTC-funded housing increases owner turnover, reduces neighborhood income in gentrifying areas, and increases property values in declining areas.

On balance, the available empirical evidence suggests that rent vouchers are likely to be more cost effective than the LIHTC program. Deng (2006) computes the costs associated with LIHTC-funded developments and vouchers in six U.S. metropolitan areas and finds that vouchers are generally less costly. However, it is important to note that there is considerable heterogeneity in the relative costs, depending on housing market conditions in the metropolitan area, the type of housing, and various other factors. Supply-side remedies may thus be preferred for particular targeted groups or in certain geographic areas. Certain groups, such as large households, single nonelderly persons, and the elderly, statistically have a lower chance of success in using their vouchers (Finkel and Buron 2001). There may also be markets in which the LIHTC is less costly than vouchers (DiPasquale, Fricke, and Garcia-Diaz 2003). Finally, LIHTCfunded developments may achieve better outcomes along other dimensions, such as neighborhood integration and school quality (Deng 2007). 
There are three other considerations that are relevant when thinking about the efficiency consequences of the structure of the LIHTC program specifically. First, the fact that producers need not be the claimers of credits may be beneficial for productive efficiency. If credits are not refundable and not transferable, then participation in the program will be tied to a provider's tax liability. Investable tax credits neutralize the bias toward for-profit providers inherent in a nonrefundable tax credit; this feature is particularly critical if the dominant organizational form for delivering the production is nonprofit. Such a market can also improve productive efficiency if there is heterogeneity among for-profit providers and more efficient providers do not have sufficient tax liability to utilize the full value of the credits.

In this sense, the provision of investable tax credits under the LIHTC is closely analogous to the widespread use of leasing as a means of transferring tax benefits (such as depreciation allowances) among firms. The leasing market allows firms facing relatively low marginal tax rates to benefit from investment incentives by allowing a firm facing a high marginal tax rate to be the legal owner of a piece of equipment. Specifically, Congress's experiment with "safe harbor" leasing removed most obstacles for the transfer of tax benefits through leasing arrangements as part of the Economic Recovery Tax Act of 1981 (see Warren and Auerbach 1982). This provision proved to be short-lived because of perceived abuses, and these concerns have limited more expansive efforts in the leasing domain. However, the leasing market continues to serve this basic function today. Investable tax credits accomplish the same separation of the legal tax beneficiary from the agent undertaking the targeted activity. This analogy also makes clear that transferability of tax benefits is not a unique feature of the LIHTC and has important precedents elsewhere in the tax system.

Second, investors claim credits over a 10 -year horizon. This provides a mechanism for the developer to receive up-front financing for the project while maintaining the ability of the government to enforce program guidelines after the project is built through the threat of recapture of credits from investors. This structure may therefore be preferable to direct subsidies or refundable credits that allocate the entire subsidy to the developer prior to project completion.

Finally, the investable nature of the program allows for the creation of delegated monitors to ensure compliance with housing agency and IRS requirements. Without the investable feature of the program, housing agencies and the IRS would be exclusively monitoring compliance of the many projects. With investable tax credits, monitoring is largely undertaken by the investors and their agents (often accounting firms) since their 
entire economic return for their investment is contingent on compliance. If there are differential monitoring capabilities, this delegation of monitoring can be an important dimension to the desirability of the LIHTC. ${ }^{23}$

Note that, in practice, the incentives for investors to monitor depend on the government oversight of the program. The IRS requires state housing agencies to develop compliance monitoring programs that meet certain federal guidelines and report cases of noncompliance. However, the IRS has no specific authorization to evaluate or audit state housing agencies to ensure that they are actually meeting these federal guidelines, and some evidence suggests that the agencies may not in fact always be fully compliant with their oversight responsibilities (GAO 1997). As discussed, the IRS rarely recaptures credits in practice, and it is not clear whether this is a result of effective monitoring and high project compliance or simply poor government oversight.

\section{Distribution of LIHTC Tax Expenditure}

Determining the true economic incidence of the LIHTC program is quite challenging for several reasons. Credit allocation formulas reflect a range of factors, including development costs and other received subsidies. In addition, states often allocate credits to developers willing to serve particular target populations or meet affordability guidelines that are stricter than federal requirements. Finally, most low-income housing projects receive additional federal supply- and demand-side subsidies, making it difficult to isolate the effects of the LIHTC. We focus instead on examining the distribution of three groups affected by the program: providers of low-income housing, investors in LIH credits, and low-income households that benefit from the program.

\section{A. Distribution of Providers}

As discussed above, an advantage of the "investable" feature of the LIHTC program is that it levels the playing field between for-profit and nonprofit developers. Federal law requires states to reserve $10 \%$ of LIHTC funds for projects with nonprofit developers, but this requirement does not appear to be binding in practice. Figure 6 illustrates the share of LIHTC-funded projects developed by nonprofit developers by year placed into service. This share increased rapidly in the early years of the program, peaked at over 35\% in 1998, and has since declined slightly to $25 \%$ in 2003 . Some states do have additional nonprofit set-asides or favor nonprofits in their QAPs (Gustafson and Walker 2002), but it 


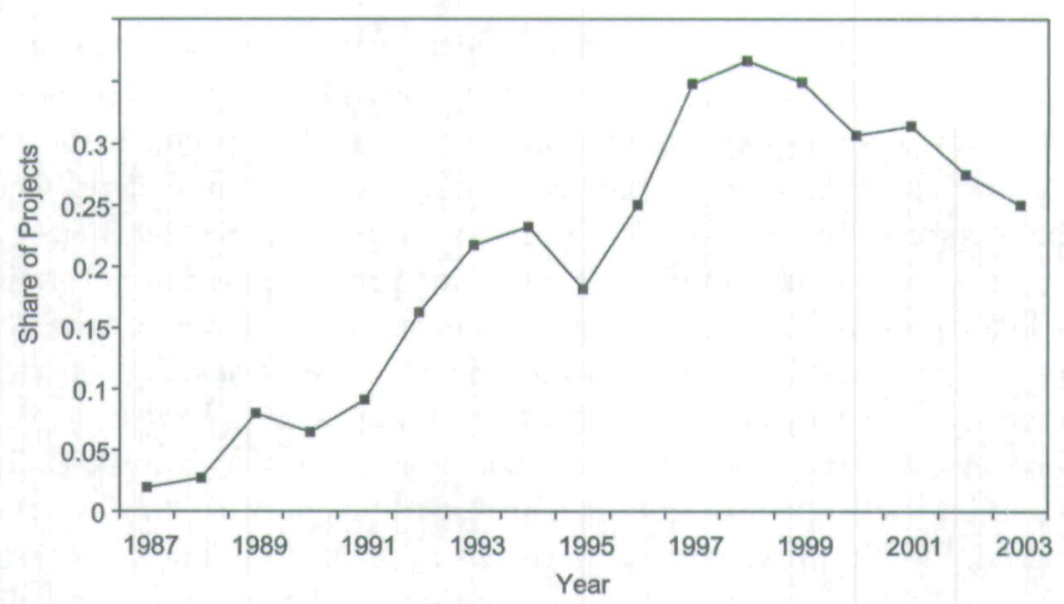

Fig. 6. Share of projects completed by a not-for-profit developer. Source: U.S. Housing and Urban Development LIHTC database. Year refers to year placed in service.

is unlikely that these provisions alone can explain the observed levels of participation of nonprofits in this market.

\section{B. Distribution of Credit Claimants}

\section{Individuals}

A surprising feature of individual LIHTC investors is that they are small: between 1987 and 2002, the average credit among claimers was slightly more than $\$ 3,000$. The number of claimants has remained fairly constant over time, but the credit claimed per return has declined substantially, as shown in figure 7. Among claimers, the average credit per return almost halved between 1995 and 2002, declining from $\$ 4,100$ to $\$ 2,100$ in real terms. This implies both an overall shift toward corporate investors and a shift toward smaller investments among remaining individual investors.

To examine the distribution of individual claimants, an approximation of cash income can be constructed from the public-use data files. ${ }^{24} \mathrm{Fig}$ ure 8 plots the share of the annual value of credits claimed by individuals by income category between 1999 and 2002. There are two features to note. First, the distribution is hump shaped in each year. This is not surprising: low-income individuals may not have tax liability to offset, and higherincome individuals (except those at the very top of the distribution) are more likely to be subject to the AMT. Second, the distribution of credits 


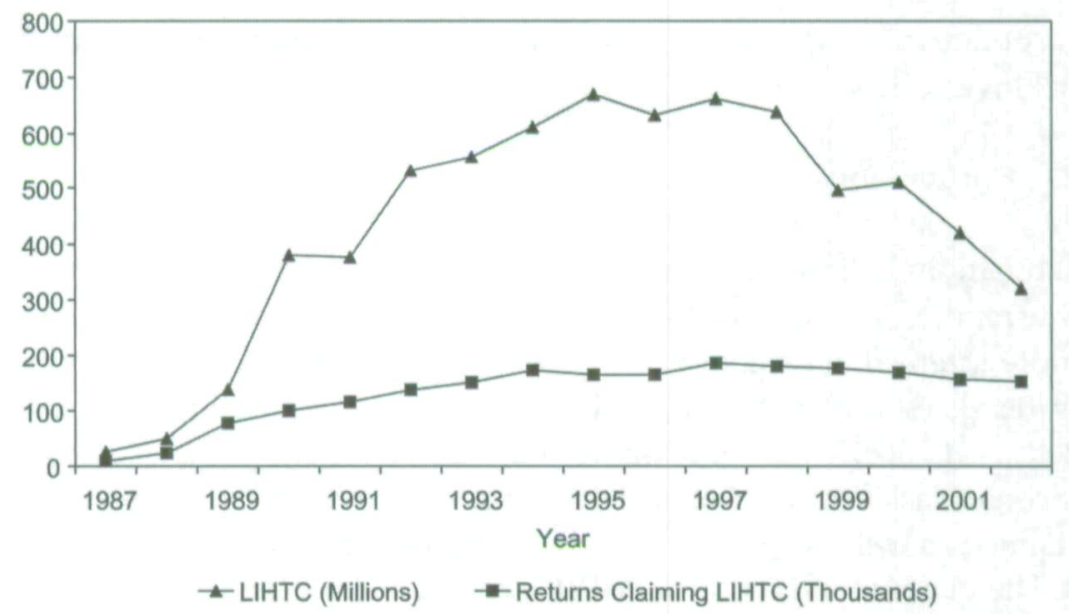

Fig. 7. LIHTC claimed by individual investors. Source: Public-use sample of individual tax returns (1987-2002). LIHTC claimed is calculated from the LIHTC line item in the tentative general business tax credit calculation.

claimed shifts noticeably down the income distribution between 2000 and 2001. In particular, the share of credit value claimed by those in the $\$ 100,000-\$ 250,000$ income category declines and appears to shift to the two income categories that are immediately below. ${ }^{25}$ These findings suggest that the AMT may have significant effects on the distribution of credit claimants and may help to explain both the overall shift toward

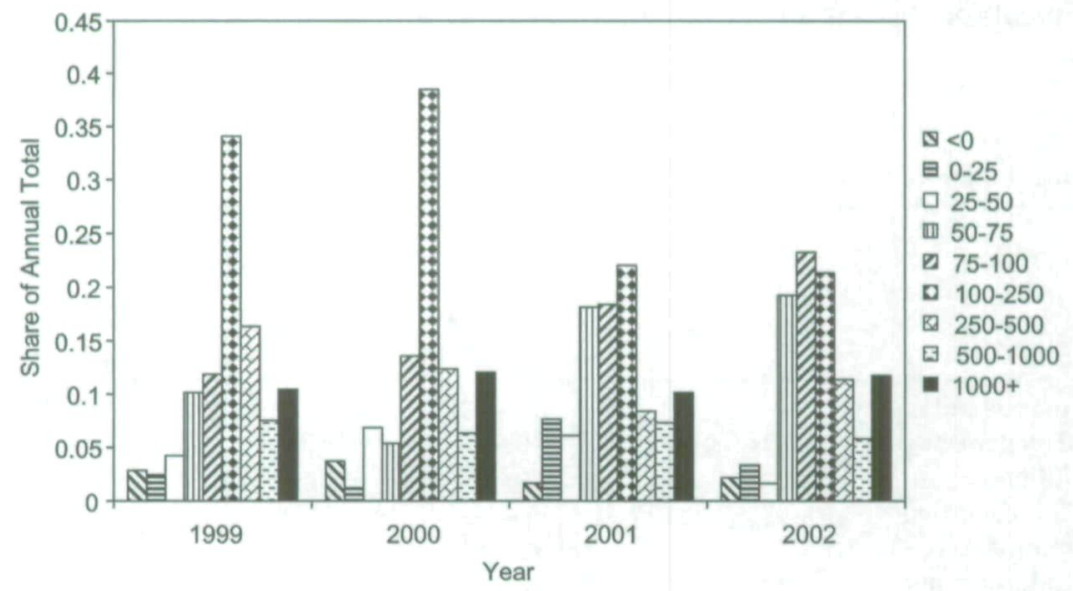

Fig. 8. Distribution of claimants by income. Source: Public-use sample of individual tax returns (1987-2002). LIHTC claimed is calculated from the LIHTC line item in the tentative general business tax credit calculation. Income refers to an approximation of cash income (see the text for details). 
corporate investors and the move toward lower-income, smaller individual investors. ${ }^{26}$

\section{Corporations}

Tabulations by income category are not available in the published corporate reports. The reports do tabulate claims by sector, which is perhaps a more interesting categorization for corporate claimants. Table 1 illustrates the share of annual credit value claimed by various sectors in 2000 and 2006. We include data from the five sectors in the Statistics of Income classification that account for the largest shares of credit value claimed as well as data for the real estate and rental and leasing sectors.

The majority of corporate credits are claimed by corporations in two sectors: finance and insurance and management of companies (holding companies). These two sectors have also accounted for a larger share of LIH credit dollars claimed over time. Together, corporations in these sectors claimed $65 \%$ of corporate credit dollars in 2000 and $89 \%$ in 2006. There is nothing in the structure of the LIHTC program alone that suggests that claiming of credits should be so concentrated across sectors. These findings strongly suggest that corporations in these sectors derive additional benefits from investments in low-income housing.

Finally, it is interesting to note that the real estate sector accounts for a negligible share of credits claimed. In part, this suggests that the separation of the provision of the service from the tax beneficiary allowed by investable tax credits has been important.

Table 1

Distribution of Corporate Claimants by Selected Sectors

\begin{tabular}{lcc}
\hline & \multicolumn{2}{c}{$\begin{array}{c}\text { Share of Annual Value of } \\
\text { Corporate Credits } \\
\text { Claimed }\end{array}$} \\
\cline { 2 - 3 } & 2000 & 2006 \\
\hline Finance and insurance & 33.4 & 42.9 \\
Management of companies (holding companies) & 31.5 & 45.6 \\
Utilities & 9.61 & NA \\
Manufacturing & 14.7 & 4.11 \\
Information & 5.43 & 3.56 \\
Real estate and rental and leasing & 1.02 & .06 \\
\hline
\end{tabular}

Source: Public table 21 of the Corporation Complete Report from the IRS. LIHTC claimed is calculated from the LIHTC line item in the tentative general business tax credit calculation. Note: The table includes the five sectors that account for the largest shares of credits claimed as well as the real estate sector. 


\section{Distribution of Beneficiaries}

Overall, it appears that the program is successful in providing affordable housing to households with below-average incomes, but it may not benefit those with the very lowest incomes. This is not surprising since the income limits for rent-restricted units are $50 \%-60 \%$ of area median income, although the additional use of vouchers or other rent subsidies may help to make the units affordable for lower-income households. A survey of properties placed into service between 1992 and 1994 indicates that three-quarters of households in LIHTC properties had income below $50 \%$ of the area median and $40 \%$ had income below $30 \%$ of the area median income (GAO 1997). Thirty-nine percent of resident households received direct rental assistance, and their average income was $25 \%$ of the area median. Similar patterns have been observed in other surveys of LIHTC properties (Ernst \& Young 1997). We do not attempt to examine the effects of the program on other (nonresident) low-income households.

\section{Recent Tax Reforms}

Congress has responded to the recent problems in the LIHTC market by adopting various measures to encourage the supply of low-income housing, within the context of its overall strategy of "economic stimulus." The HERA, enacted in July 2008, included provisions designed both to make $\mathrm{LIH}$ credits more attractive to investors and to expand the scale of the LIHTC program (see Keightley 2009). In particular, HERA established a floor for the annual credit rate (as a percentage of a project's eligible basis) obtained by investors in LIH credits. The act also increased LIHTC allocations to the states by $10 \%$ for 2008 and 2009 .

In addition, HERA allowed LIH credits to be used to offset AMT liability. A number of housing advocates had argued strongly for enabling credits to be used against AMT liability in order to make credits attractive to investors who are subject to the AMT or who are concerned about facing the AMT over the lifetime of the credits. Since credit allocations are fixed, this provision should not substantially affect tax expenditure on the program. ${ }^{27}$ In theory, this change may shift credit claiming back to individual investors (especially those with higher incomes), since this group is more likely to be constrained by the AMT. This could shift the distribution of investors, which could affect the effectiveness of the program in producing low-income housing as well as the types of projects built under the program. Projects with corporate investors tend to have 
lower syndication costs (Ernst \& Young 1997) and are likely to be more effective at ex post monitoring than a diffuse group of small individual investors, resulting in a reduction of risk and higher credit prices. A shift back to individual investors could therefore decrease the amount of equity financing available for low-income housing. The changing distribution of investors may also influence the types of projects that are financed under the program. A report by the National Association of Home Builders (2005), for example, argued that individual investors tend to prefer smaller projects and may be more likely to prefer rural projects as well as projects catering toward special-needs populations. However, the application of credits against the AMT may have a small effect relative to the growing use of LIH credits by corporations against CRA requirements. To the extent that this effect dominates, credit claiming may continue to shift increasingly toward corporations.

More recently, the ARRA, signed into law by President Obama on February 17, 2009, marked a significant departure for the LIHTC through the introduction of a credit exchange program. Specifically, ARRA authorized the Treasury to make cash grants to the states in lieu of part of their LIHTC allocations (Keightley 2009). For example, a state was permitted to elect to receive as cash grants up to $40 \%$ of its $2009 \mathrm{LIH}$ credit allocations (as well as to receive grants in exchange for unused credits for 2008). The federal government will pay $\$ 0.85$ for each $\$ 1$ of LIH credits given up by the state. The idea underlying this provision is that states would award these funds to developers to pursue projects that conform to LIHTC requirements. These projects need not have any other LIHTC funding, although developers are required to demonstrate that they have made a good-faith effort to obtain equity investment. The funds awarded in this way are not taxable income to the recipients and do not reduce the project's eligible basis for LIHTC purposes. This LIHTC exchange program will essentially bypass the current depressed market for LIH credits. The provision is anticipated to have a substantial budgetary impact, relative to the overall size of the LIHTC program. ${ }^{28}$

\section{Conclusion}

The LIHTC program has become the primary federal program subsidizing the development of low-income housing and appears to have broad support among policy makers, low-income housing advocates, developers, and institutional investors. Recent and proposed reforms to the program have been in the direction of further expansion, and the structure of the LIHTC has been replicated in other related federal and state programs. 
Several features of the LIHTC program distinguish it from traditional supply-side provision or subsidization. The unbundling of the service provider and the tax beneficiary has potential advantages for competition and productive efficiency. This unbundling also creates better incentives for ex post monitoring and compliance in theory, although it is not clear whether these benefits are being realized in practice. However, the LIHTC structure also means that the success of the program in delivering affordable housing thus depends on the incentives of a variety of market participants.

Tax expenditures under the program are quite predictable, but the supply of housing provided for a given level of tax expenditure (even abstracting from general equilibrium effects) can vary. Corporations are now the primary investors in LIH credits, and their incentives may reflect features of not only the LIHTC program specifically but also related programs, such as CRA requirements.

The recent crisis has illustrated the potential vulnerability of the program to aggregate market conditions. Several provisions of recent policy reforms have loosened the supply of credits or made the terms of their use more favorable but have not altered the program's fundamental structure. However, the replacement of some LIHTC allocations by cash grants represents a significant (albeit partial and perhaps temporary) shift in program design from the "investable tax credit" model discussed earlier toward the direct subsidy approach. In view of this, analysis of the relative merits of the LIHTC structure and a traditional subsidy appears more pertinent than ever.

\section{Endnotes}

We thank Bill Apgar, Lily Batchelder, Jeff Brown, Rob Dietz, Tom Holtmann, Christopher Marquis, Tom Neubig, Michael Novogradac, Richard Peiser, Michael Schler, Abby Sigal, Alvin Warren, David Weisbach, and participants in the NBER Economics of Tax Expenditure conference and the 2009 Tax Policy and the Economy conference for helpful discussions and comments. We are grateful to Ben Feigenberg, Jill Gentry, Adam Hallowell, and Ealy Ko for providing excellent research assistance and to the Harvard University Taubman Center for State and Local Government, the Harvard Real Estate Academic Initiative, and the Fitzgerald Gubernatorial Fund for Maine for generous research support.

1. Expenditure growth in the early years of the program primarily reflects lags between credit allocation and claiming; later expenditure growth reflects expansions in annual credit allocations.

2. In addition, 15 states have enacted state LIHTC programs to supplement the federal LIHTC program. Most of these programs have a structure similar to that of the federal program.

3. For other overviews of the program, see Burman (2005) and U.S. Treasury (2008).

4. In particular, projects must meet either a $20-50$ rule (at least $20 \%$ of the units in the development must be rent restricted and occupied by households with incomes at or below $50 \%$ of the area median income) or a $40-60$ rule (at least $40 \%$ of the units in the development 
must be rent restricted and occupied by households with incomes at or below $60 \%$ of the area median income).

5. States may, e.g., require developers to meet stricter rent requirements or remain in compliance for a longer period than mandated by the federal guidelines.

6. More specifically, the qualified basis is the product of the eligible basis, the amount of all applicable depreciable development costs, and the applicable fraction. The eligible basis includes most depreciable costs but excludes such costs as the acquisition costs of land and permanent financing costs. The project may be eligible for a "basis boost" of $30 \%$ if it is located in a U.S. Housing and Urban Development-designated high-cost area. The applicable fraction is either the fraction of units or the fraction of floor space (whichever is lower) reserved as low-income units. A potential concern with this method is that the subsidy amount is set ex ante without a mechanism to adjust the subsidy ex post for changes in operating costs or area median income; see Usowski and Hollar (2008) for further discussion.

7. Technically, the eligible basis is multiplied by an "applicable percentage" that is meant to produce a credit allocation equivalent to the present values given above. This leads to applicable percentages of approximately $9 \%$ and $4 \%$, respectively. In practice, the percentages are set by the Treasury monthly and fluctuate with interest rates. If the amount of credits required to attract enough equity finance to fill the financial deficit is less than this calculated amount, the project receives the lower amount. The 2008 HERA set a floor for the credit rate for new construction completed before 2014 at $9 \%$.

8. There is perhaps an analogy here with Ferejohn's (1986) account of the Food Stamp Program, which argues that the program was enacted as the result of a (seemingly unnatural) coalition between rural legislators with farming constituencies and urban legislators representing the urban poor.

9. The LIHTC also can create odd political coalitions in other policy dimensions. For example, LIHTC advocates suggested that the initial proposal for dividend exemption in 2003 would depress the market for tax credits and opposed the proposal on that basis.

10. We are grateful to Tom Holtmann at JCT for several helpful discussions on these issues.

11. The credits included in the general business tax credit are then subject to a stacking order that determines which credits are claimed first.

12. See http://www.irs.gov/pub/irs-soi/weber.pdf for sampling details.

13. There are some conditions placed on investors who wish to sell their interests in LIHTC properties. In particular, until recently, the investor had to purchase a "recapture bond," which guarantees payment to the Treasury in the event of tax credit recapture due to noncompliance. This was repealed under HERA.

14. Until 2008, LIH credits could not be used to offset AMT liability. Therefore, these tentative credits are presumably not actually claimed by investors.

15. Cummings and DiPasquale (1999) find similar patterns in their surveyed properties.

16. The low probability of punishment may arise from low noncompliance or ineffective monitoring. The IRS is largely dependent on monitoring by state housing agencies, and a GAO review found a number of potential problems in state oversight procedures (GAO 1997).

17. Many participants employ an after-tax yield to measure pricing more accurately to catch the temporal aspects of the credits. Participants then use comparisons between these yields and municipal bonds to benchmark appropriate pricing. When yields are lower than municipal bonds, most participants believe that CRA incentives, discussed below, are operative.

18. Marquis and Guthrie (2007) discuss the interactions between the CRA and the LIHTC at length. They cite Federal Reserve analyses of bank mergers that highlight LIHTC investments as ways of satisfying CRA requirements. Marquis and Guthrie go on to argue that states design their LIHTC programs, in part, to help banks address CRA guidelines in order to foster merger activity.

19. As discussed earlier, this price corresponds to one that may have exceeded $\$ 1$ when tax credits are appropriately discounted; this point does not, however, affect the magnitude of the postcrisis decline in prices.

20. For examples of projects that have lost financing as a result, see Terry Pristin, "Shovel Ready, but Investor-Deprived," New York Times, May 6, 2009. 
21. However, the end of the housing bubble has increased housing affordability, as house prices have declined from their previously excessive levels toward their fundamental values.

22. See Cummings and DiPasquale (1999) for estimates of the total development costs of housing produced under the LIHTC program and Deng (2006) for comparisons with the voucher program.

23. Thanks to Michael Novogradac for highlighting this point to us.

24. In particular, we use the following definition for income: cash income = adjusted gross income - saving and loan tax refunds + individual retirement account deduction + student loan interest deduction + alimony paid deduction + tuition and fees deduction + health savings account deduction $+1 / 2$ of self-employment tax + penalty on early withdrawal of saving + self-employed health insurance deduction + medical savings account deduction + Keogh deduction + tax-exempt interest + nontaxable social security benefits min (other income, 0 ). Not all components are available in all years, so we construct a measure as close as possible to the above definition in each year.

25 . Those with very high incomes are likely to have regular tax liability that exceeds the AMT. This may be one explanation for why the claim share for those in the highest income category ( $\$ 1$ million and above) remains fairly stable over this period. The change in distribution of individual investors could be more precisely attributed to the AMT by comparing changes in the distribution across states with high vs. low shares of AMT taxpayers. This is unfortunately not possible in the public-use files since the state of residence is not available for those with adjusted gross incomes greater than $\$ 200,000$.

26. Individual investments in LIH credits are also limited by passive loss limitations. We thank Rob Dietz for highlighting this point to us.

27. In theory, allowing credits to be used to offset the AMT could increase tax expenditures under the program if some investors were previously unable to claim purchased credits after being hit by the AMT. This effect seems likely to be small since investors were well aware of the AMT provisions and made purchasing decisions taking into account the likelihood that they would be subject to the AMT over the life of the credits. In addition, investors could make use of carryforward allowances and the secondary market for credits, making it likely that most credits allocated were eventually claimed.

28. The JCT estimates a cost of $\$ 419$ million over the 10-year budget horizon (Keightley 2009).

\section{References}

Baum-Snow, N., and J. Marion. 2009. "Effects of Low-Income Housing Developments on Neighborhoods." Journal of Public Economics 93:654-66.

Burman, L. 2005. "Low-Income Housing Credit." In NTA Encyclopedia of Taxation and Tax Policy, ed. J. J. Cordes, R. D. Ebel, and J. G. Gravelle. Washington, DC: Urban Institute Press.

Coate, S., S. Johnson, and R. Zeckhauser. 1994. "Pecuniary Redistribution through In-Kind Programs." Journal of Public Economics 55:1-40.

Cummings, J. L., and D. DiPasquale. 1999. "The Low-Income Housing Tax Credit: An Analysis of the First Ten Years." Housing Policy Debate 10, no. 2:251-307.

Deng, L. 2006. "The Cost-Effectiveness of the Low-Income Housing Tax Credit Relative to Vouchers: Evidence from Six Metropolitan Areas." Housing Policy Debate 16:469-511.

—. 2007. "Comparing the Effects of Housing Vouchers and Low-Income Housing Tax Credits on Neighborhood Integration and School Quality." Journal of Planning Education and Research 27:20-35.

DiPasquale, D., D. Fricke, and D. Garcia-Diaz. 2003. "Comparing the Costs of Federal Housing Assistance Programs." Federal Reserve Bank of New York Economic Policy Review 9, no. 2:147-66. 
Eriksen, M. 2009. "The Market Price of Low-Income Housing Tax Credits." Journal of Urban Economics 66, no. 2:141-49.

Eriksen, M., and S. Rosenthal. 2008. "Crowd Out Effects of Place-Based Subsidized Rental Housing: New Evidence from the LIHTC Program." Unpublished manuscript, University of Georgia.

Ernst \& Young. 1997. "The Low Income Housing Tax Credit: The First Decade." Unpublished manuscript, Ernst \& Young.

- 2003. "The Impact of the Dividend Exclusion Proposal on the Production of Affordable Housing." Unpublished manuscript, Ernst \& Young.

—. 2005. "Understanding the Dynamics III: Housing Tax Credit Investment Performance." Unpublished manuscript, Ernst \& Young.

Federal Reserve Bank of Dallas. 2009. "Low-Income Housing Tax Credits in Texas: Achievements and Challenges." Banking and Community Perspectives, no. 2 (May).

Ferejohn, J. A. 1986. "Logrolling in an Institutional Context: A Case Study of Food Stamps Legislation." In Congress and Policy Change, ed. G. Wright, L. Rieselbach, and L. Dodd. New York: Agathon.

Finkel, M., and L. Buron. 2001. Study on Section 8 Voucher Success Rates. Vol. 1: Quantitative Study of Success Rates in Metropolitan Areas. Cambridge, MA: Abt Associates.

GAO (General Accounting Office). 1997. Tax Credits: Opportunities to Improve Oversight of the Low Income Housing Program. GAO/GGD/RCED-97-55. Washington, DC: GAO.

- 2007. Tax Policy: New Markets Tax Credit Appears to Increase Investment by Investors in Low-Income Communities, but Opportunities Exist to Better Monitor Compliance. GAO-07-296. Washington, DC: GAO.

Gibbons, S., and A. Manning. 2006. "The Incidence of UK Housing Benefit: Evidence from the 1990's Reforms." Journal of Public Economics 90:799-822.

Gustafson, J., and J. C. Walker. 2002. "Analysis of State Qualified Allocation Plans for the Low-Income Housing Tax Credit Program." Unpublished manuscript, Urban Institute, Washington, DC.

JCT (Joint Committee on Taxation). Various years. "Estimates of Federal Tax Expenditures." Report, JCT, Washington, DC.

Keightley, Mark P. 2009. An Introduction to the Design of the Low-Income Housing Tax Credit. Report no. RS22389. Washington, DC: Congressional Research Service.

Malpezzi, S., and K. Vandell. 2002. "Does the Low-Income Housing Tax Credit Increase the Supply of Housing?" Journal of Housing Economics 11:360-80.

Marquis, C., and D. Guthrie. 2007. "State Activism and the Hidden Incentives behind Bank Acquisitions." Unpublished manuscript, Harvard Business School.

National Association of Home Builders. 2005. "Increasing Individual Investor Demand for the LIHTC." White Paper, National Association of Home Builders, Washington, DC.

Olsen, E. O. 2003. "Housing Programs for Low-Income Households." In MeansTested Transfer Programs in the U.S., ed. Robert Moffitt. Chicago: University of Chicago Press (for NBER).

Rice, D., and B. Sard. 2007. "The Effects of the Federal Budget Squeeze on LowIncome Housing Assistance." Unpublished manuscript, Center on Budget and Policy Priorities, Washington, DC.

Sinai, T., and J. Waldfogel. 2005. "Do Low-Income Housing Subsidies Increase the Occupied Housing Stock?" Journal of Public Economics 89:2137-64. 
Susin, S. 2002. "Rent Vouchers and the Price of Low-Income Housing." Journal of Public Economics 83:109-52.

Usowski, K., and M. Hollar. 2008. "Social Policy and the U.S. Tax Code: The Curious Case of the Low-Income Housing Tax Credit." Unpublished manuscript, U.S. Department of Housing and Urban Development, Washington, DC.

U.S. Treasury. 2008. "Low-Income Housing Tax Credits: Affordable Housing Investment Opportunities for Banks." Community Development Insights, February, U.S. Treasury, Washington, DC.

Warren, A. C., Jr., and A. J. Auerbach. 1982. "Transferability of Tax Incentives and the Fiction of Safe Harbor Leasing." Harvard Law Review 95:1752-86.

Weisbach, D. A. 2006. "Tax Expenditures, Principal Agent Problems, and Redundancy." Washington University Law Review 84:1823-60. 
Copyright of NBER/Tax Policy \& the Economy (University of Chicago Press) is the property of University of Chicago Press and its content may not be copied or emailed to multiple sites or posted to a listserv without the copyright holder's express written permission. However, users may print, download, or email articles for individual use. 